\title{
UPAYA MENINGKATKAN HASIL BELAJAR ILMU PENGETAHUAN ALAM (IPA) DENGAN METODE PEMBELAJARAN MIND MAP
}

\author{
HERI RISWANTO \\ 087878635181 \\ Mahasiswa Program Studi Pendidikan Fisika, Fakultas Teknik, Matematika \& Ilmu \\ Pengetahuan Alam Universitas Indraprasta PGRI

\section{DASMO} \\ 085691644769 \\ amo0903unindra@gmail.com \\ Program Studi Pendidikan Fisika, Fakultas Teknik, Matematika \& Ilmu Pengetahuan Alam \\ Universitas Indraprasta PGRI
}

\begin{abstract}
The purpose of this research to analize the influence mind map method concerning the result of studying science with controling the student's ability in the beginning. This research used experiment method with analize ANAKOVA. The sample which is used for this research are the students in VIII SMP with 60 students which spread in VIII.E and VIII.F class of SMPN 275 Jakarta. The results of this research are: First, controlling influence the students' ability in the beginning, there is difference result of studying science which is significant between the students who study by using mind map method and using conventional method. $\left(F_{\text {hitung }}=12,01>F_{\text {tabel }}=4,01\right)$ Second, controlling influence the students' ability in the beginning, the result of study science, The students who study by using mind map method is better than using conventional method $\left(t_{\text {hitung }}=3,345>t_{\text {tabel }}=1,672\right)$.
\end{abstract}

Keywords: Mind Map, Studying Science and Science

\section{PENDAHULUAN}

Pentingnya mata pelajaran IPA berbanding terbalik dengan minat belajar peserta didik. Sampai saat ini, masih banyak peserta didik yang memandang IPA sebagai salah satu mata pelajaran yang sulit. Diduga hal tersebut merupakan salah satu penyebab hasil belajar IPA yang masih tergolong rendah. Berdasarkan survei yang penulis lakukan di SMP Negeri 275 Jakarta, diperoleh hasil sebagai berikut (table 1.1).

Tabel 1.1 Nilai Ujian Nasional SMPN 275 Jakarta Tahun 2009 - 2013

\begin{tabular}{|c|c|c|c|c|c|c|}
\hline \multirow[b]{2}{*}{ No } & \multirow[b]{2}{*}{$\begin{array}{l}\text { Tahun } \\
\text { Pelajaran }\end{array}$} & \multicolumn{4}{|c|}{ Nilai Ujian Nasional } & \multirow[b]{2}{*}{ Rata-rata } \\
\hline & & Matematika & $\begin{array}{l}\text { Bahasa } \\
\text { Indonesia }\end{array}$ & $\begin{array}{l}\text { Bahasa } \\
\text { Inggris }\end{array}$ & IPA & \\
\hline 1. & $2008 / 2009$ & 7,59 & 7,95 & 7,35 & 7,43 & 7,58 \\
\hline 2. & $2009 / 2010$ & 7,27 & 8,10 & 6,99 & 6,50 & 7,21 \\
\hline 3. & $2010 / 2011$ & 7,41 & 8,31 & 7,01 & 6,71 & 7,36 \\
\hline 4. & $2011 / 2012$ & 8,45 & 8,55 & 7,11 & 8,36 & 8,11 \\
\hline 5. & $2012 / 2013$ & 7,49 & 8,39 & 7,56 & 7,43 & 7,71 \\
\hline & Rata-rata & 7,64 & 8,26 & 7,20 & 7,28 & - \\
\hline
\end{tabular}


Melihat rata-rata per mata pelajaran, jelas bahwa hasil belajar IPA peserta didik masih tergolong rendah dibandingkan dengan hasil belajar mata pelajaran lainnya. Misalnya jika dibandingkan dengan mata pelajaran Matematika dan Bahasa Indonesia maka hasil belajar IPA masih berada dibawahnya.

Pada umumnya peserta didik belajar IPA di kelas tanpa melakukan persiapan sebelumnya, sehingga kemampuan awal peserta didik terbatas. Kondisi ini mengakibatkan informasi yang diberikan guru tidak dengan cepat diterima, sehingga guru perlu mengulang informasi tersebut. Oleh sebab itu, seorang guru diharapkan mampu mengendalikan kemampuan awal peserta didiknya.

Kemampuan awal merupakan kemampuan yang telah dimiliki oleh peserta didik sebelum mengikuti pembelajaran. Peserta didik yang memiliki kemampuan awal yang setara bisa menjadi cemerlang atau terpuruk pada satu mata pelajaran, bergantung pada kecintaan atau kebenciannya pada pelajaran itu (Barbara, 2007: 123). Sebagai guru penting mengetahui kemampuan awal peserta didiknya guna menentukan strategi dan gaya mengajar yang sesuai. Selain itu juga dapat digunakan untuk mengetahui pengatahuan peserta didik sehingga guru mengetahui kesiapan siswa dalam menerima materi pelajaran yang akan disampaikan.

Sehubungan dengan hal tersebut maka kemampuan awal yang dimiliki peserta didik sebelum memulai pelajaran baru, berpengaruh terhadap kemampuan peserta didik untuk memahami materi pelajaran yang akan dihadapinya. Hal ini terjadi jika antara kemampuan awal dan materi pelajaran baru menunjukan adanya relevansi, terutama jika kemampuan awal tersebut merupakan kemampuan persyaratan terhadap pelajaran berikutnya.

Selain kemampuan awal, penggunaan metode pembelajaran yang tepat dalam proses belajar mengajar akan sangat berpengaruh terhadap ketercapaian pemahaman peserta didik. Tentunya semua metode pembelajaran yang pernah diterapkan selama ini mempunyai kelebihan dan kekurangan. Terlepas dari semua itu, metode pembelajaran yang sering diterapkan oleh guru-guru saat ini masih cenderung hanya mengaktifkan salah satu belahan otak saja. Menurut Porter dan Hernacki (1999:28), "pada hakekatnya otak manusia terbagi menjadi dua belahan, yaitu belahan otak kiri dan belahan otak kanan. Masing-masing kedua belahan ini bertanggung jawab terhadap cara berpikir dan masing-masing memiliki spesialisasi dalam kemampuan-kemampuan tertentu".

Kedua belahan otak manusia ini memiliki tugas dan cara kerja yang berbeda. Menurut Buzan (2013:48), "tugas-tugas otak kanan antara lain berkaitan dengan irama, kesadaran ruang, imajinasi, melamun, warna, dimensi, dan tugas-tugas yang membutuhkan kesadaran holistik atau gambaran keseluruhan. Sedangkan tugas-tugas otak kiri berkaitan kata-kata, logika, angka, urutan, daftar dan analisis". Umumnya manusia hanya memfungsikan salah satu belahan otaknya saja, ada yang dominan belahan otak kirinya dan ada pula yang dominan belahan otak kanannya.

Begitu juga dalam belajar, jika peserta didik bisa mengaktifkan kedua belahan otaknya secara efektif, maka peserta didik akan dengan mudah menerima pelajaran yang diberikan guru. Bukan hanya itu, kemampuan logika peserta didik akan lebih berkembang dibandingkan mereka harus menghafal kata demi kata dan kalimat demi kalimat. Metode pembelajaran yang dapat mengoptimalkan kedua belah sisi otak manusia tersebut adalah metode pembelajaran mind map (peta pikiran). Mind map merupakan istilah teknik pemetaan pikiran untuk membantu membuka seluruh potensi dan kapasitas otak yang masih tersembunyi. Pemetaan pikiran ini akan melibatkan kedua sisi otak secara bersamaan, yaitu otak kanan dan otak kiri. Metode ini mempermudah memasukan informasi kedalam otak dan untuk kembali mengambil informasi dari dalam otak. 
Mind map adalah sistem penyim-panan, penarikan data, dan akses yang luar biasa untuk perpustakaan raksasa, yang sebenarnya ada dalam otak anda yang menakjubkan (Buzan, 2013:12). Jensen (2002:95) berpendapat bahwa: "Mind Map (peta pikiran) sangat bermanfaat untuk memahami materi, terutama materi yang telah diterima oleh siswa dalam proses pembelajaran. Mind Map (peta pikiran) bertujuan membuat materi pelajaran terpola secara visual dan grafis yang akhirnya dapat membantu merekam, memperkuat, dan mengingat kembali informasi yang telah dipelajari".

Metode mind map memiliki kebaikan-kebaikan antara lain adalah: (a) Dapat mengoptimalkan otak kanan dan otak kiri, karena mind map bekerja dengan gambar, warna dan kata-kata sederhana. (b) Dapat menghemat catatan, karena dengan mind map bisa meringkas satu bab materi dalam setengah lembar kertas. (c) Pembelajaran lebih efektif, dan efisisien, karena pada dasarnya cara kerja mind map sama dengan cara kerja dasar otak, yaitu tidak tersusun sistematis, namun lebih pada bercabang-cabang seperti pohon. Pola ini dapat mempermudah proses recall pada setiap hal yang pernah dipelajari. (d) Dapat meningkatkan daya kreatifitas siswa dan guru, karena siswa dan guru akan terangsang untuk membuat gambar-gambar atau warna-warna pada mind map agar terlihat lebih menarik. (e) Mempertajam daya analisa dan logika siswa, karena siswa tidak lagi dituntut untuk mencatat buku sampai habis kemudian menghapalnya. Namun lebih kepada pemahaman dan kreatifitas untuk dapat menghubungkan topik umum dengan subsub topik bahasan.

\section{METODE}

Penelitian ini menggunakan metode eksperimen terhadap 60 peserta didik kelas VIII SMP Negeri 275 Jakarta. Sementara itu, penelitian ini meng-gunakan pendekatan ANAKOVA untuk menganalisis data. Menurut Supardi (2011: 390) penelitian dengan pendekatan ANAKOVA adalah sebuah penelitian ekperimen yang membandingkan antara hasil post-test pada kelompok eksperimen dengan kelompok kontrol, setelah mengendalikan pengaruh pre-test (kemampuan awal). Desain penelitian eksperimen dari model penelitian ini dapat digambarkan sebagai berikut.

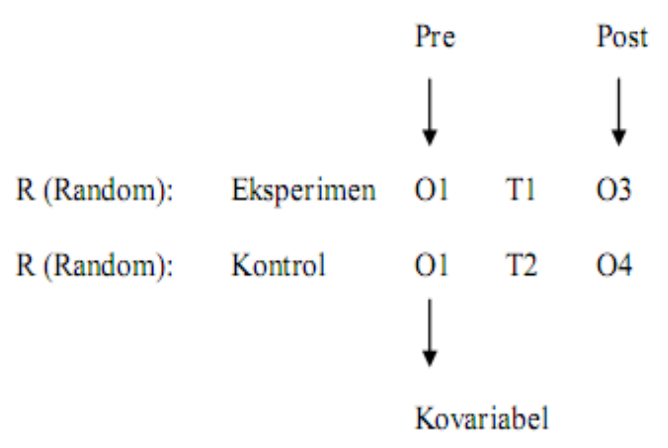

Keterangan:

$\mathrm{O}_{1}$ dan $\mathrm{O}_{2}$ adalah observasi variabel kovariant (pretest)

$\mathrm{O}_{3}$ dan $\mathrm{O}_{4}$ adalah observasi variabel tergantung/kriteria (posttest)

$\mathrm{T}_{1}$ dan $\mathrm{T}_{2}$ adalah kegiatan perlakuan/ treatment pada kelompok eksperimen dan control.

\section{HASIL DAN PEMBAHASAN}

Hasil

Secara deskriptif, data penelitian ini dapat dinyatakan dalam Tabel 2. 
Tabel 2. Analisis Deskriptif

\begin{tabular}{lllll}
\hline \multirow{2}{*}{$\begin{array}{c}\text { Statistik } \\
\text { Deskriptif }\end{array}$} & \multicolumn{2}{c}{ Mind map } & \multicolumn{2}{l}{ Konvensional } \\
\cline { 2 - 5 } & $\begin{array}{l}\text { Pre } \\
\text { test }\end{array}$ & $\begin{array}{l}\text { Post } \\
\text { test }\end{array}$ & Pre test & $\begin{array}{l}\text { Post } \\
\text { test }\end{array}$ \\
\hline Maksimum & 20 & 21 & 19 & 20 \\
Minimum & 13 & 12 & 10 & 8 \\
Rata-rata & 16,70 & 17,13 & 16,30 & 14,93 \\
Median & 16,24 & 17,1 & 15,50 & 14,90 \\
Modus & 18,67 & 18,50 & 16,75 & 14,61 \\
Simpangan baku & 2,11 & 2,13 & 2,32 & 3,01 \\
\hline
\end{tabular}

Sumber: Data primer yang diolah

Dari table 2, terlihat bahwa rata-rata skor untuk kemampuan awal kelompok eksperimen (metode mind map) sebesar 16,7. Nilai ini setara dengan 83,5 dalam skala 100. Kondisi ini menunjukkan bahwa kemampuan awal kelompok eksperimen tergolong baik dengan nilai di atas KKM $(70,00)$. Nilai siswa yang berada di bawah KKM berjumlah $4(13,33 \%)$ peserta didik. Sementara itu nilai median dan modusnya masingmasing sebesar 16,24 (setara dengan 81,25) dan 18,67 (setara dengan 93,35) dengan standar deviasi sebesar 2,11.

Sementara itu, rata-rata untuk skor kemampuan awal kelompok kontrol sebesar 16,30. Nilai ini setara dengan 81,50 dalam skala 100 . Kondisi ini menunjukkan bahwa kemampuan awal kelompok kontrol tergolong baik dengan nilai di atas KKM. Nilai siswa yang berada di bawah KKM berjumlah $8(16,67 \%)$ peserta didik. Sementara itu nilai median dan modusnya masing-masing sebesar 15,50 (setara dengan 77,50) dan 16,75 (setara dengan 83,75) dengan standar deviasi sebesar 2,32.

Selanjutnya, nilai rata-rata untuk skor hasil belajar IPA kelompok eksperimen sebesar 17,13. Nilai ini setara dengan 81,57 dalam skala 100. Kondisi ini menunjukkan bahwa hasil belajar IPA kelompok eksperimen tergolong baik dengan nilai di atas KKM. Nilai siswa yang berada di bawah KKM berjumlah $3(6,67 \%)$ peserta didik. Sementara itu nilai median dan modusnya masing-masing sebesar 17,1 (setara dengan 81,43 ) dan 18,50 (setara dengan 88,10) dengan standar deviasi sebesar 2,13.

Nilai rata-rata untuk skor hasil belajar IPA kelompok kontrol sebesar 14,93. Nilai ini setara dengan 71,10 dalam skala 100. Kondisi ini menunjukkan bahwa hasil belajar IPA kelompok kontrol tergolong kurang baik karena hanya sedikit diatas nilai KKM. Nilai siswa yang berada di bawah KKM berjumlah 14 (46,67\%) peserta didik. Sementara itu nilai median dan modusnya masing-masing sebesar 14,90 (setara dengan 70,95) dan 14,61 (setara dengan 69,57) dengan standar deviasi sebesar 3,01.

Sebelum melakukan uji hipotesis, peneliti melakukan uji analisis persyataran data melalui pegujian normalitas dan homogenitas. Kriteria pengujian norma-litas dilakukan dengan membandingkan nilai $\mathrm{L}_{\text {hitung }}$ dan $\mathrm{L}_{\text {tabel }}$, dimana data dikatakan normal jika $\mathrm{L}_{\text {hitung }}<$ $\mathrm{L}_{\text {tabel. }}$ Berdasarkan hasil pengolahan, semua data berdistribusi normal. Hasil pengujian normalitas dapat dilihat dalam table berikut.

Table 3. Uji Normalitas

\begin{tabular}{cccl}
\hline Kelompok & $\mathrm{L}_{\text {hitung }}$ & $\mathrm{L}_{\text {tabel }}$ & Kesimpulan \\
\hline $\mathrm{X}_{1}$ & 0,115 & 0,161 & normal \\
$\mathrm{X}_{2}$ & 0,108 & 0,161 & normal \\
$\mathrm{Y}_{1}$ & 0,125 & 0,161 & normal \\
$\mathrm{Y}_{2}$ & 0,097 & 0,161 & Normal \\
\hline
\end{tabular}


Pengujian pesyaratan analisis data selanjutnya dilakukan dengan uji homogenitas. Data dikatakan homogen jika nilai $\mathrm{F}_{\text {hitung }}<\mathrm{F}_{\text {tabel. }}$. Berdasarkan hasil pengujian diperoleh kesimpulan bahwa kelompok data bersifat homogen. Hasil pengujian homogenitas dapat dilihat dalam table berikut.

Table 4. Uji Homogenitas

\begin{tabular}{cccc}
\hline Kelompok & $\mathrm{F}_{\text {hitung }}$ & $\mathrm{F}_{\text {tabel }}$ & $\begin{array}{c}\text { Kesimpula } \\
\mathrm{n}\end{array}$ \\
\hline $\mathrm{X}_{1}$ dan $\mathrm{X}_{2}$ & 1,326 & 1,861 & homogen \\
$\mathrm{Y}_{1}$ dan $\mathrm{Y}_{2}$ & 1,748 & 1,861 & homogen \\
\hline \multicolumn{5}{l}{ Sumber: Data primer yang diolah }
\end{tabular}

Setelah semua asumsi persyaratan analisis terpenuhi, pengujian dilanjutkan dengan dengan pengujian hipotesis, yakni dengan teknik ANAKOVA. Dari pengujian hipotesis main effect diperoleh nilai $\mathrm{F}_{\mathrm{h}}$ antarkolom sebesar 12,01. Nilai ini lebih besar dibandingkan dengan nilai $F_{t}$ yang bernilai 4,01. Dengan membandingkan nilai antara $F_{h}$ dan $\mathrm{F}_{\mathrm{t}}$ tersebut, maka uji hipotesis ini memenuhi kriteria $\mathrm{H}_{1}$. Artinya dengan mengontrol/mengendali-kan pengaruh kemampuan awal (X), terdapat perbedaan hasil belajar IPA (Y) peserta didik yang belajar dengan metode pembelajaran mind map dan metode pembelajaran konvensional. Jika dilihat berdasarkan perbedaan nilai rata-rata, kelompok siswa yang diberikan metode pembelajaran mind maping memiliki nilai ratarata $17,13(81,57)$. Sementara yang diajar dengan metode konvensional sebesar 14,93 $(71,10)$.

Sementara itu, dari pengujian simple effect diperoleh $t_{\text {hitung }}$ sebesar 3,345 dan $t_{\text {tabel }}$ 1,672. Dengan demikian disimpulkan bahwa dengan mengontrol/ mengendalikan pengaruh kemampuan awal (X), secara sigifikan hasil belajar IPA (Y) peserta didik yang belajar menggunakan metode pembelajaran mind map lebih besar dari pada yang menggunakan metode pembelajaran konvensional.

\section{Pembahasan}

Penelitian ini berhasil membuktikan bahwa metode pembelajaran memiliki peran penting dalam mengoptimalkan hasil belajar peserta didik. Menurut Sanjaya (2007:147), "metode adalah cara yang digunakan untuk mengimplementasikan rencana yang sudah disusun dalam kegiatan nyata agar tujuan yang telah disusun tercapai secara optimal". Hal ini berarti metode digunakan untuk merealisasikan strategi yang telah ditetapkan sehingga tujuan dari pembelajaran dapat tercapai. Keberhasilan implementasi strategi pembelajaran sangat tergantung pada cara guru menggunakan metode pembelajaran, karena suatu strategi pembelajaran hanya mungkin dapat diimplementasikan melalui penggunaan metode pembelajaran.

Mind map sebagai sebuah metode pembelajaran merupakan metode yang baik dalam membantu proses berfikir otak secara teratur karena menggunakan teknik grafis yang berasal dari pemikiran manusia yang bermanfaat untuk menyediakan kunci-kunci universal sehingga membuka potensi otak. Jensen (2002: 95) berpendapat, "Mind Map (peta pikiran) sangat bermanfaat untuk memahami materi, terutama materi yang telah diterima oleh siswa dalam proses pembelajaran. Mind Map (peta pikiran) bertujuan membuat materi pelajaran terpola secara visual dan grafis yang akhirnya dapat membantu merekam, memperkuat, dan mengingat kembali informasi yang telah dipelajari”.

Peserta didik yang belajar menggunakan metode pembelajaran mind map mempunyai pemahaman yang lebih baik dibandingkan dengan peserta didik yang menggunakan metode pembelajaran konvensional. Hasil penelitian ini sesuai atau relevan 
dengan penelitian sebelumnya yaitu penelitian yang dilakukan oleh Silaban dan Napitupulu (2012) yang menyatakan bahwa pembelajaran advance organizer dengan mind mapping berpengaruh secara signifikan terhadap hasil belajar siswa (analisis dengan SPSS 17 diperoleh bahwa $p$ value (Sig.(1-tailed)) < 0,050 (dimana p value (Sig.(2-tailed)) $=0,002$ ).

Hal ini juga sejalan dengan pendapat Jensen (2002:95), “Mind Map (peta pikiran) sangat bermanfaat untuk memahami materi, terutama materi yang telah diterima oleh siswa dalam proses pembelajaran". Mind Map (peta pikiran) bertujuan membuat materi pelajaran terpola secara visual dan grafis yang akhirnya dapat membantu merekam, memperkuat, dan mengingat kembali informasi yang telah dipelajari sehingga metode pembelajaran mind map sangat efektif digunakan dalam pembelajaran.

Hasil penelitian ini juga diperkuat oleh pendapat Ausubel yang dikutip Hudojo (2002: 10) menyatakan bahwa pembelajaran yang menggunakan Mind Map (peta pikiran) dapat membuat suasana belajar menjadi bermakna karena pengetahuan atau informasi yang baru diajarkan menjadi lebih mudah terserap siswa. Lebih lanjut Ausubel yang dikutip Hudojo (2002: 10) menerangkan bahwa pembelajaran dengan menggunakan metode Mind Map (peta pikiran), akan membantu siswa dalam meringkas materi pelajaran yang diterima oleh siswa pada saat proses pembelajaran sehingga menjadi lebih mudah dipahami oleh siswa. Tentu saja hal tersebut akan berpengaruh positif terhadap hasil belajar IPA peserta didik.

Dengan demikian hasil penelitian ini semakin memperkuat hasil penelitian sebelumnya. Metode pembelajaran Mind Map sangat cocok danefektif digunakan dalam proses belajar mengajar di SMP Negeri 275 Jakarta khususnya dan sekolah lain pada umumnya setelah mengontrol/mengendalikan pengaruh kemampuan awal.

\section{PENUTUP}

\section{Simpulan}

Berdasarkan hasil pengujian hipotesis penelitian dan analisis pengolahan data, maka dapat disimpulkan sebagai berikut. Pertama, dengan mengontrol/ mengendalikan pengaruh kemampuan awal, terdapat perbedaan hasil belajar IPA yang signifikan antara peserta didik yang belajar menggunakan metode pembelajaran mind map dengan yang menggunakan metode pembelajaran konvensional. Kedua, dengan mengontrol/ mengendalikan pengaruh kemampuan awal, hasil belajar IPA peserta didik yang belajar menggunakan metode pembelajaran mind map lebih besar daripada yang belajar menggunakan metode pembelajaran konvensional.

\section{Saran}

Beberapa saran yang perlu disampaikan terkait hasil penelitian diatas adalah: Guru diharapkan bisa menjadikan metode mind mapping sebagai salah satu alternatif metode pembelajaran yang bisa digunakan dalam proses pembelajaran sains.

\section{DAFTAR PUSTAKA}

Barbara, Given K. 2007. Brain-Based Teaching. Penerjemah: Lala Herawatidarma. Bandung: Kaifa.

Buzan, Tony. 2013. Buku Pintar Mind Map. Jakarta: PT. Gramedia Pustaka Utama.

Jensen, Eric dan Karen Makowitz. 2002. Otak Sejuta Gygabite: Buku Pintar Membangun Ingatan Super. Bandung : Kaifa.

Porter, B. dan Hernacki. 1999. Quantum Learning: Membiasakan Belajar Nyaman dan Menyenangkan. Bandung: Kaifa. 
Sanjaya, Wina. 2007. Strategi Pembelajaran Berorientasi Standar Proses Pendidikan. Jakarta: Kencana Prenada Media Grup.

Silaban,Ramlan dan Masita Anggraini Napitupulu. 2012. Pengaruh Media Mind Mapping terhadap Kreatifitas dan Hasil Belajar Kimia Siswa SMA pada Pembelajaran Menggunakan Advance Organizer. Penelitian.FMIPA Universitas Negeri Medan. 